\title{
Nutrient and Bioactive Composition of Five Gabonese Forest Fruits and Their Potential Contribution to Dietary Reference Intakes
}

Robert Fungo ${ }^{1,5}$, John H Muyonga ${ }^{1 *}$, Judith Laure Ngondi ${ }^{2}$, Christian Mikolo-Yobo ${ }^{3}$, Donald Midoko Iponga ${ }^{3}$, Alfred Ngoye ${ }^{3}$, Sylvanus Odjo ${ }^{4}$, Erasmus Nchuaji Tang ${ }^{2}$ and Julius Chupezi Tieguhong ${ }^{5,6}$

${ }^{1}$ School of Food Technology, Nutrition \& Bio-Engineering, Makerere University, P.O. Box 7062 Kampala , Uganda

${ }^{2}$ Department of Biochemistry, University of Yaoundé 1, Yaoundé, Cameroon

${ }^{3}$ Institut de Recherche en Ecologie Tropicale (IRET), Centre National de la Recherche Scientifique et Technique (CENAREST), Libreville, Gabon

${ }^{4}$ University of Liege, Gembloux Agro-Bio Tech, Passage des Déportés, 2, B-5030 Gembloux, Belgium

${ }^{5}$ Forest Genetic Resources Programme, Bioversity International, Via dei Tre Denari, 472/a 00057, Maccarese , Rome, Italy.

${ }^{6}$ African Natural Resources Centre, African Development Bank, 01 BP 1387 Abidjan 01 - Côte d'Ivoire

*School of Food Technology, Nutrition \& Bio-Engineering, Makerere University, P.O. Box 7062 Kampala, Uganda Email: rfungom@caes.mak.ac.ug 


\begin{abstract}
Widely consumed forest fruits in Gabon, were analyzed for nutrient and bioactive compositions and their potential contributions to meeting the nutrient requirements of consumers. Edible pulps of Panda oleosa, Gambeya lacourtiana and Poga oleosa contained substantial amounts of bioactive compounds; flavonoids (13.5-22.8 mg/100g), proanthocyanins $(2.4-7.6 \mathrm{mg} / 100 \mathrm{~g})$, polyphenols (49.6-77.3 mg/100g) and vitamin C (6.7-97.7 mg/100g). The highest content of $\beta$ carotene $(76.6 \mu \mathrm{g} / 100 \mathrm{~g})$ was registered in fruits of Pseudospondias longifolia. The fruits of $P$. oleosa had the highest essential minerals Fe, $\mathrm{Zn}$ and Se. If a child aged 1 to 3 years consumed about $200 \mathrm{~g}$ or if a non-lactating and non-pregnant woman consumed $300 \mathrm{~g}$ of P. oleosa, $A$. lepidophyllus, G. lacourtiana, P. longifolia and P. oleosa, they could obtain substantial RDI ranging between $20-100 \%$ for energy, vitamins $\mathrm{C}$ and $\mathrm{E}$, iron, magnesium, iron and zinc. Forest fruits can considerably contribute towards the human nutrient requirements. Based on the results of this study, forest foods should be considered in formulating policies governing food and nutrition security in Gabon.
\end{abstract}

Key words: Wild fruits, phytochemicals, malnutrition and health 


\section{Introduction}

In developing countries such as Gabon, forest foods provide income, essential nutrients and energy requirements to millions of urban and rural populations [1]. However, low intake of diversified diets in developing countries including Gabon, is among the top ten risk factors contributing to the health disorders related to inadequate intake of nutrients in Africa [2,3]. Rural poor populations are often among the most vulnerable ones because of the less diversified diets they consume [3]. An estimated $75 \%$ of the population (including rural people) in Gabon predominantly consume processed cereals and meats [4]. According to the World Health Organization (WHO), a daily intake of over $400 \mathrm{~g}$ of fruits and vegetables per person has a potential to protect against diet-related non-communicable diseases and micronutrient deficiencies [5]. Micronutrient rich vegetables and fruits including the ones sourced from forests are among the least consumed foods by Gabonese, making their diets less diverse [4]. Nondiversified diets can result in negative consequences on an individual's wellbeing and development, because these diets may not meet essential nutrient requirements [6], exacerbating micronutrient deficiencies, obesity and non-communicable diseases. Gabon is among the top ten countries in sub-Saharan Africa, with the highest prevalence of obesity and non-communicable diseases [4,7]. Available data reveals that overweight and obesity prevalence in Gabon has increased from $11.9 \%$ in 1995 to $20.4 \%$ in 2014 [4,7], with an average annual growth rate of $2.88 \%$. This trend is more likely to increase if no alternative measures are taken.

Promoting sustainable consumption of the readily available nutrient dense forest foods in Gabon could go a long way in addressing health disorders related to malnutrition. Studies carried out in Cameroon [8,9] and Nigeria [10], emphasized the superiority of forest foods in contributing to essential nutrient and bioactive contents than the conventional and imported processed foods. For 
example, in Cameroon, forest foods were found to contribute to improved food and nutrition security of communities adjoining forests [9]. They have potential to address both macro and micronutrient deficiencies and non-communicable disease disorders related with inadequate intake of bioactive compounds [8,9]. Cameroonian forest fruits provide considerable amounts of vitamins $\mathrm{C}, \mathrm{A}$ and $\mathrm{E}$, selenium, calcium, iron and zinc to children aged between 1-3 years and women of reproductive age to have a healthy living [9]. On the other hand, forest foods also act as a safety net during times of severe food shortage, hence providing essential nutrients and food $[11,12]$. However, in Gabon, there is paucity of studies on nutrient composition and bioactive content of forest fruits. Thus, the primary aim of this study was to determine the nutrient content of five Gabonese forest plant foods. The five species were Panda oleosa, Poga oleosa, Pseudospondias longifolia, Gambeya lacourtiana and Afrostyrax lepidophyllus. The secondary objective of the study was to explore the nutritional potential contribution of these forest fruits to the dietary requirements of both women and children.

\section{Materials and methods}

\subsection{Sampling sites}

The study samples were collected from villages surrounding two sites, which are owned by timber concessionaires. The first site was the "Compagnie Equatoriale des Bois (CEB)" owned by Precious Wood Inc, located in the South-East and the "Convention Provisoire AmènagementExploitation Transformation (CPAET)" of Bayonne located in the South West of the country (Figure. 1). The CEB is located at latitude: $00^{0} .83^{\prime} 36^{\prime \prime}$; longitude: $13^{0} .320^{\prime} 68^{\prime \prime}$ around Okondja town in the "Sebe Bricolo Departement" (Province of Upper Ogoouè). The forest concession covers an area of 615,000 hectares and employs about 1,460 people. 


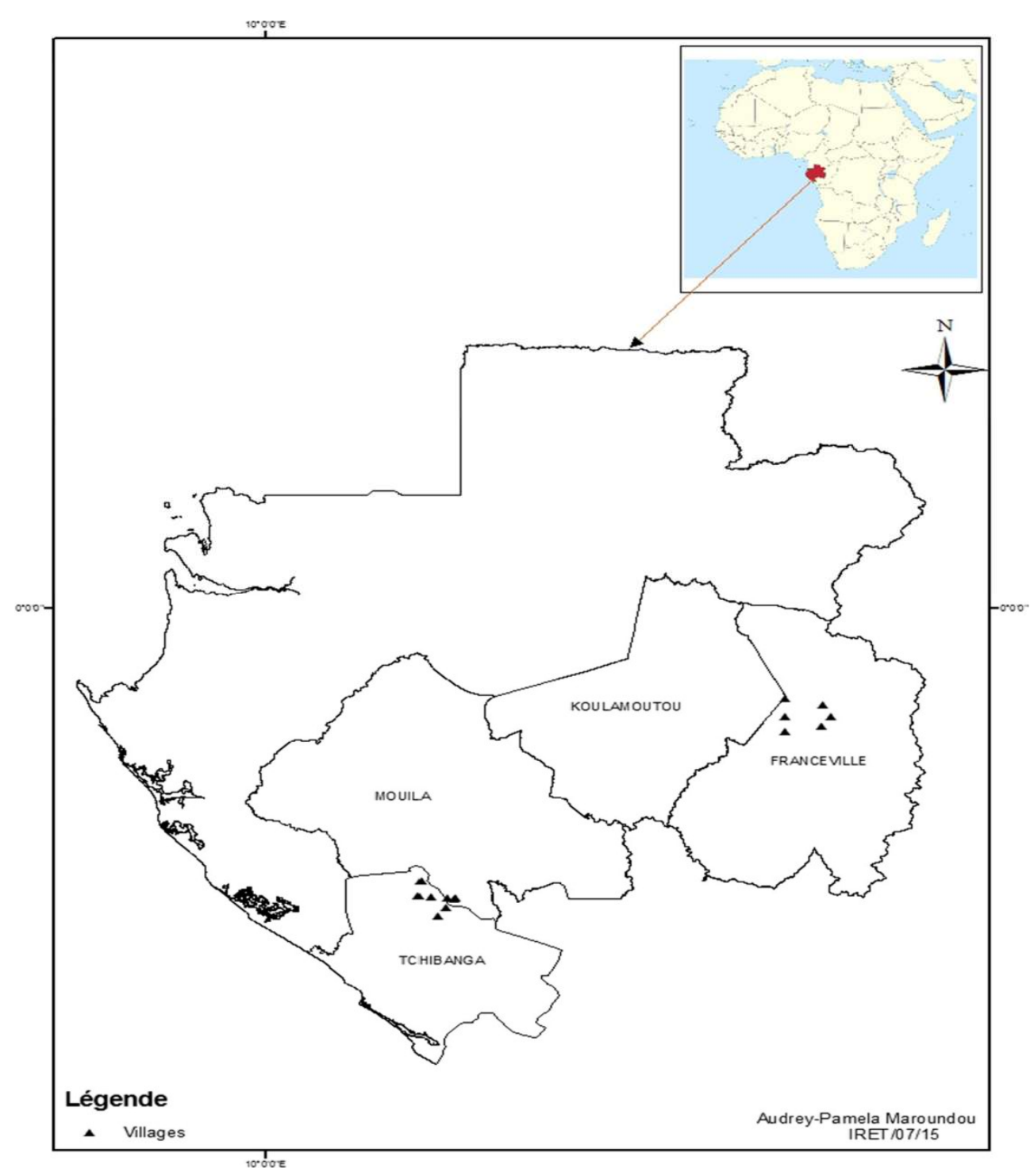

Figure 1: Study villages in two regions of the two timber concessions

The population adjoining this timber concession is made up of about 14,000 people [13]. Their main source of income is chainsaw milling with agriculture poorly developed in this area $[13,14]$. Fruit samples in this site were collected around the former Industrial License $2 / 90$ that is located in the Eastern part of the concession. The second site (CPAET) located between the provinces of Nyanga and Ngounie' covers an area of about 72,113 ha. In this forest concession, several ethnic groups reside around it and the total population is estimated at about 1,600 people [14]. Due to limited employment opportunities around the forest concession, people around 
CPEAT primarily depend on the collection of forest foods and related natural resources including forest fruits for household consumption.

\subsection{Forest fruits sampling and sample preparation}

Six readily available and widely consumed edible parts of forest fruits species including; $P$. oleosa, P. oleosa, P. longifolia, G. lacourtiana and A. lepidophyllus were sampled from selected villages in the two sites (Figure. 2). The villages where fruit samples were collected were selected on the basis of their accessibility and proximity to the annually allocated timber logging areas. The study villages were stratified according to ethnicity and the level of forest exploitation by the logging companies. A multi-stage cluster sampling technique involving one stage of purposeful selection and one stage of randomization was employed. In the first stage the most accessible administrative districts within each site and fitting the village selection criterion listed above were purposefully selected. In the second stage, three villages were randomly selected from the selected districts of each site. From the South East, samples were collected from the villages of Mbouga and Otundou while in the South West, samples were collected from the villages of Okila, Tondondo, Dougassou and Nyangadougou. In Mbouga and Otundou, fruits of Panda oleosa and Poga oleosa were referred to as "dibetou" and "afos" respectively while in the Okila, Tondondo, Dougassou and Nyangadougou fruits of P. longifolia, G. lacourtiana and A. lepidophyllus were natively called "ofoss", "abami” and "ngali” respectively. 


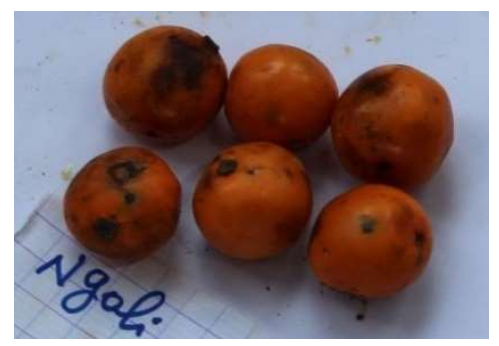

Afrostyrax lepidophyllus

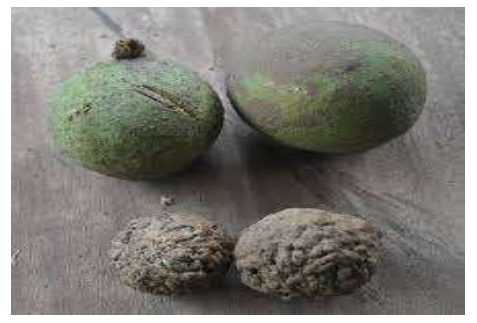

Panda oleosa

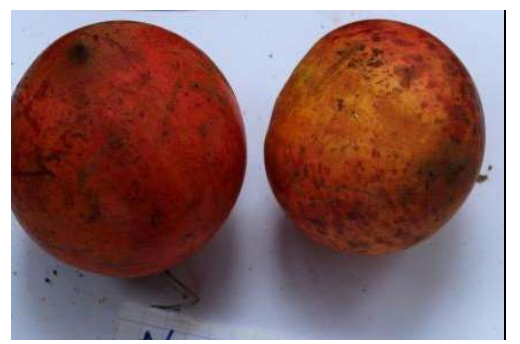

Gambeya lacourtiana

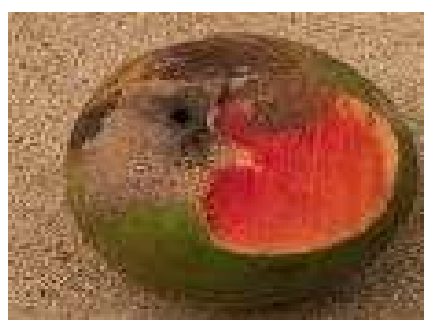

Poga oleosa

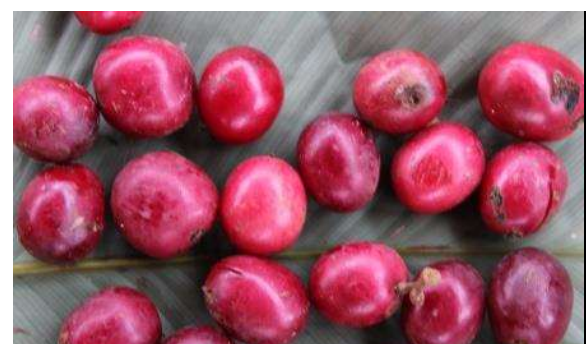

Pseudospondias longifolia

Figure 2: Edible portions of $A$. lepidophyllus, G. lacourtiana, P. longifolia, P. oleosa and P. oleosa.

From each study village, five mature fresh fruits per species, were sampled from different points and packaged in a perforated plastic container that was labeled and kept in an ice box container. The collected samples were then transported to the "Institut de Recherche en Ecologie Tropicale" (IRET), Libreville and stored in a refrigerator at $4^{\circ} \mathrm{C}$ for one night. The next day, the samples were transported to Cameroon by air, for nutrient and bioactive compound analyses at the Nutrition and Biochemistry laboratory of the University of Yaounde I. At the laboratory, the samples were washed with deionized water and conserved in a refrigerator at $4^{\circ} \mathrm{C}$. For each fruit species, two fruits out of the five per village were randomly selected for edible pulp and/or nut extraction. The pulp from the fruits were mashed in a blender and then the extracted edible pulp per species, were divided into three sub samples. The first sub sample was immediately sealed in clean polyethylene bags and conserved at $-20^{\circ} \mathrm{C}$. The second fresh pulp was used for vitamin and 
bioactive compound analyses, while the third was analyzed for moisture content. Dried samples were conserved for proximate analysis (excluding moisture content).

\subsection{Nutrient analyses of the fruits}

For nutrient analyses of the edible portions of the fruits, the reagents, reference standards and solvents were purchased from Merck (Darmstadt, Germany). All the analyses were conducted in triplicate.

\section{$2.4 \quad$ Proximate analysis}

The total moisture content was determined by measuring the weight loss of $5 \mathrm{~g}$ portion of fresh fruits pulp, using the vacuum oven method 934.01 [15]. The total fat content was determined using the ether extraction method 920.39. The inorganic matter (total ash) was determined using method 942.05 [15]. The organic matter of the six samples was excluded by heating them at 550 ${ }^{0} \mathrm{C}$ overnight, and the residue being the inorganic matter (ash). The total crude fiber content was determined using the official AOAC method 978.10 [15] while the total crude protein content was determined using the Kjeldahl 984.13 method. The total carbohydrate content was calculated using the difference method of Greenfield \& Southgate [16] as follows; $100 \%$ - (crude protein $\%$ + ash $\%+$ crude fat $\%+$ moisture $\%$ ). In each edible portion, metabolizable carbohydrates were calculated following the method recommended by Greenfield \& Southgate (2003):; 100\% (crude protein $\%+$ ash $\%+$ crude fat $\%+$ moisture $\%+$ crude fiber $\%$ ).

\subsection{Minerals}

For mineral content determination the fruit samples were digested using nitric/sulphuric acid (1:1 $\mathrm{v} / \mathrm{v})$ mixtures [15], prior to mineral content determination. The atomic absorption spectrophotometric method 975.03B [15], was used to determine Calcium [Ca], copper [Cu], magnesium $[\mathrm{Mg}]$ and zinc $[\mathrm{Zn}]$ contents. Iron $(\mathrm{Fe})$ and selenium $[\mathrm{Se}]$ were determined using the atomic absorption spectrophotometric methods 999.11 [15] and 996.16 (G) [15] respectively. 
Potassium $[\mathrm{K}]$ and sodium $[\mathrm{Na}]$ were separately determined calorimetrically, using the flame emission photometric method 956.01 [15] while Phosphorous [P] content was determined using the gravimetric method 966.01 [15]. The atomic absorption spectrophotometer (AAS) and calorimeter were both calibrated against a series of standard solutions containing the elements under investigation. Mineral concentrations of each sample were quantified by comparison, against the standard curves. Standard curves were obtained after calibrations of each instrument was performed using a series of standards for each corresponding pure mineral of sodium, magnesium, iron, zinc, selenium, potassium and calcium and phosphorous and they were prepared from a $1000 \mathrm{ppm}$ single stock solution made up with $2 \%$ nitric acid. The external calibrations were then run in the same analytical sequence as the samples [15].

\subsection{Bioactive compounds}

Vitamin C, $\beta$-carotene, Vitamin E, flavonoids, polyphenols and proanthocyanins

(20 g) of fresh edible portion of each fruit sample was used to extract the bioactive compounds. For total phenolic and total flavonoid contents analyses, the extraction procedure described by Fungo et al., [8] was used. The pulp of the fruits was carefully removed from seed, grated and blended to fine pulp using a blender (Magic Line, Model MFP 000, Nu World Ind. (Pty) Ltd, Johannesburg, South Africa) with stainless steel blades. The fine pulp was stirred continuously with $50 \mathrm{~mL}(80 \% \mathrm{v} / \mathrm{v})$ methanol for $24 \mathrm{~h}$. The extract was filtered and the filtrate was centrifuged at $4000 \mathrm{X}$ g for 15 min using a centrifuge (Hitachi Model CR22N CE; Hitachi Koki Co., Ltd Life sciences instruments, Tokyo, Japan). The supernatant was stored at $4^{\circ} \mathrm{C}$ prior to use within two days. Total phenolic and total flavonoid contents in the methanolic extract, were determined using the Folin-Ciocalteu's calorimetric method [17] and the aluminum chloride calorimetric method [18] respectively. The absorbance of phenolic compounds was measured at $765 \mathrm{~nm}$ 
while the absorbance of flavonoids, was measured at $415 \mathrm{~nm}$ using UV-VIS spectrophotometer (U- 2001; Hitachi Instruments Inc., Tokyo, Japan). Quantification of total phenolic content was realized using the standard curve of gallic acid prepared in $80 \%$ methanol $(\mathrm{v} / \mathrm{v})$ and results were expressed in milligrams gallic acid equivalent (GAE) per gram fresh weight (fw) of fruits [19]. Quantification of total flavonoids was done on the basis of standard curve of quercetin prepared in $80 \%$ methanol and the results were expressed in milligram quercetin equivalent (QE) per gram fruit weight. The extraction of proanthocyanins was done using $70 \%(\mathrm{v} / \mathrm{v})$ ethanol in water overnight at room temperature and the content in the extracts was determined spectrophotometrically by the pH differential method described by Giusti et al., [20]. The UVvisible spectrophotometer (U- 2001; Hitachi Instruments Inc., Tokyo, Japan) was used to read absorbance at 530 and $700 \mathrm{~nm}$. The total proanthocyanins content was calculated according to the standard curve of pure cyanidin- 3-O-glucoside (Darmstadt, Germany) and expressed as cyanidin-3-O-glucoside (Cyn-3-O-G) mg/100 g fresh weight. $\beta$-carotene content was determined colorimetrically using AOAC method 970.64 [21] while vitamin E was determined using Spectrophotometer (UV/VISIBLE) as previously described by Fungo et al., [8]. Extraction of $\beta$ carotene was done using xylene and separated using column chromatography, while vitamin E (tocopherol) was extracted using alcoholic sulphuric acid and absolute alcohol method 971.30 [21]. The $\beta$-carotene and vitamin E were determined by measuring absorbance at $470 \mathrm{~nm}$ and $270 \mathrm{~nm}$ respectively against blank samples. Standard curves were made with pure $\beta$-carotene standard and pure tocopherol, and the results expressed as $\mathrm{mg} \beta$-carotene equivalent and $\mathrm{mg}$ vitamin E equivalent per 100g dried pulp powder. Vitamin $\mathrm{C}$ (ascorbic acid) was extracted using phosphotungstate reagent $(\mathrm{PR})$ and quantified using spectrophotometric procedures at 
absorbance of $515 \mathrm{~nm}$ against a blank [22]. Vitamin C content was calculated using the calibration curve of the standard reference of L-ascorbic acid.

\subsection{Data analysis}

Statistical analyses were carried out using SPSS version 21 statistical software. The results were expressed as means \pm standard deviations. The nutrient contribution of an average portion of forest fruits to nutrient intake recommendations of a child aged 1-3 years and a non-lactating non-pregnant woman, were calculated and expressed as a percentage of the Dietary Reference Intakes (DRI) (recommended dietary allowance) [RDA] [23,24]. The nutrient intake were calculated based on total daily food intake estimations of forest populations in Cameroon reported by Fungo et al. [8,9] and the Congo Basin forest communities reported by Yamauchi et al., [25], where children aged 1-3 years consume about $200 \mathrm{~g}$ daily and non-lactating nonpregnant woman consume an average $300 \mathrm{~g}$ of food daily. Using these daily intake estimates per individual, the possible potential impact of the forest foods on the daily nutrients requirements among children and adults was calculated.

\section{$3 \quad$ Results}

\subsection{Proximate composition}

Poga oleosa and Panda oleosa were found to have high fat and calorie contents (Table 1). The fat content in each fruit of $P$. oleosa and P. oleosa is more than 4 folds that registered in Pseudospondias longifolia, Afrostyrax lepidophyllus and Gambeya lacourtiana. The fruits of A.lepidophyllus had exceptionally high contents of proteins and dietary fiber, while $G$. lacourtiana and $P$. longifolia were found to have substantial levels of digestible carbohydrates, with contents of about $60.0 \%$. 


\subsection{Minerals}

Generally the fruits of $P$. oleosa, contained considerably high amounts of several essential minerals including; zinc, selenium and sodium (Table 2). Calcium, magnesium and iron were highest in the fruits of $A$. lepidophyllus. Although phosphorous content was remarkably high in the fruits of $P$. longifolia, generally the fruits of $P$. longifolia, substantially contained low amounts of minerals.

\subsection{Bioactive compounds}

Vitamin C, $\beta$-carotene, Vitamin E, flavonoids, polyphenols and proanthocyanins

The fruits of $G$. lacourtiana contained exceptionally high contents of bioactive compounds including; vitamin C, flavonoids, polyphenols and vitamin E (Table 3). P. oleosa was found to have considerably high contents of proanthocyanins and vitamin $\mathrm{E}$. The highest $\beta$-carotene content in the present study registered in the fruits of $P$. longifolia, is about four folds higher than the content registered in the fruits of $P$. oleosa and $P$. oleosa and 12 folds higher the content registered in A. lepidophyllus. 
Table 1: Mean (\%) edible portion 'wet basis ${ }^{\text {1 }}$ and standard deviations for proximate composition of common forest fruits consumed in Gabon

\begin{tabular}{|c|c|c|c|c|c|c|c|c|}
\hline \multirow[b]{2}{*}{ Sample } & \multicolumn{8}{|c|}{ Proximate composition mean concentrations $(\%)^{2}$} \\
\hline & $\begin{array}{l}\text { Water } \\
\text { content }\end{array}$ & Total fat & Ash & Total protein & $\begin{array}{l}\text { Total } \\
\text { carbohydrates }\end{array}$ & $\begin{array}{l}\text { Digestible } \\
\text { carbohydrates }\end{array}$ & $\begin{array}{l}\text { Total energy } \\
(\text { Kcal })^{3}\end{array}$ & $\begin{array}{l}\text { Total dietary } \\
\text { fiber }\end{array}$ \\
\hline Poga oleosa & $15.3 \pm 0.7$ & $68.5 \pm 6.4$ & $2.1 \pm 0.5$ & $2.1 \pm 0.8$ & $27.2 \pm 5.9$ & $21.1 \pm 5.9$ & 709.3 & $6.1 \pm 0.1$ \\
\hline $\begin{array}{l}\text { Pseudospondias } \\
\text { longifolia }\end{array}$ & $29.0 \pm 2.0$ & $11.1 \pm 0.3$ & $6.0 \pm 1.3$ & $2.7 \pm 0.4$ & $85.8 \pm 0.5$ & $66.4 \pm 0.7$ & 376.3 & $19.4 \pm 0.5$ \\
\hline $\begin{array}{l}\text { Afrostyrax } \\
\text { lepidophyllus }\end{array}$ & $4.6 \pm 0.7$ & $17.4 \pm 1.5$ & $7.9 \pm 0.3$ & $11.9 \pm 0.8$ & $62.8 \pm 2.2$ & $4.6 \pm 1.7$ & 222.6 & $58.1 \pm 0.8$ \\
\hline
\end{tabular}

${ }^{1}$ : Edible portion wet basis

2: Each value is the mean and standard deviation (SD) of 3 sample lots per species analyzed individually.

3: Metabolizable energy (Kcal) provided by substrates in diets = Digestible carbohydrates*4+ Total fat*9+ Total proteins*4 [8].

Table 2. Mean concentrations ( $\mathrm{mg} / \mathbf{1 0 0 g}$ ) edible portion wet basis and standard deviations of common forest fruits consumed in Gabon

\begin{tabular}{lllllllll}
\hline & \multicolumn{7}{c}{ Sample $^{1}$} & \multicolumn{7}{c}{ Mean concentrations (mg/100g) $^{\mathbf{2}}$} \\
\cline { 2 - 9 } & $\mathrm{Na}$ & $\mathrm{K}$ & $\mathrm{Ca}$ & $\mathrm{Mg}$ & $\mathrm{P}$ & $\mathrm{Fe}$ & $\mathrm{Zn}$ & $\mathrm{Se}^{3}$ \\
\hline Panda oleosa & $25.4 \pm 1.5$ & $0.004 \pm 0.01$ & $0.003 \pm 0.0006$ & $10.5 \pm 1.3$ & $0.005 \pm 0.0008$ & $17.1 \pm 1.3$ & $10.2 \pm 0.03$ & $0.7 \pm 0.1$ \\
Poga oleosa & $20.4 \pm 0.01$ & $0.002 \pm 0.0003$ & $8.1 \pm 0.01$ & $10.9 \pm 0.01$ & $0.002 \pm 0.0004$ & $20.6 \pm 0.6$ & $7.5 \pm 0.1$ & $0.1 \pm 0.01$ \\
Pseudospondias longifolia & $18.7 \pm 0.02$ & $0.006 \pm 0.003$ & $41.6 \pm 0.9$ & $21.3 \pm 0.3$ & $35.3 \pm 0.07$ & $4.4 \pm 0.01$ & $0.2 \pm 0.01$ & $0.03 \pm 0.002$ \\
Gambeya lacourtiana & $37.9 \pm 1.04$ & $0.007 \pm 0.0007$ & $0.004 \pm 0.0004$ & $0.002 \pm 0.4$ & $0.002 \pm 0.003$ & $2.4 \pm 0.1$ & $6.6 \pm 0.3$ & $0.2 \pm 0.02$ \\
Afrostyrax lepidophyllus & $8.7 \pm 0.5$ & $0.002 \pm 0.0003$ & $71.5 \pm 1.9$ & $88.5 \pm 1.9$ & $0.6 \pm 0.05$ & $23.5 \pm 1.7$ & $0.9 \pm 0.04$ & $0.02 \pm 0.002$ \\
\hline
\end{tabular}

\footnotetext{
${ }^{1}$ : Edible portion wet basis

2: Each value is the mean and standard deviation (SD) of 3 sample lots per species analyzed individually.

${ }^{3}: \mu \mathrm{g} / 100 \mathrm{~g}$
} 
Table 3. Mean concentrations (mg/100g) edible portion wet basis) and standard deviations of bioactive compounds of common forest fruits consumed in Gabon

\begin{tabular}{lllllll}
\hline Sample $^{1}$ & \multicolumn{5}{c}{ Mean concentrations (mg/100g) $^{\mathbf{2}}$} \\
\cline { 2 - 7 } & Vitamin c & $\beta$ - carotene & Vitamin E $^{3}$ & Flavonoids Polyphenols & Proanthocyanins \\
\hline Panda oleosa & $6.7 \pm 0.1$ & $17.2 \pm 0.5$ & $23.2 \pm 1.3$ & $13.5 \pm 0.5$ & $49.6 \pm 2.4$ & $7.6 \pm 0.2$ \\
Poga oleosa & $4.6 \pm 0.04$ & $17.1 \pm 0.1$ & $21.4 \pm 0.1$ & & & \\
Pseudospondias longifolia & $36.3 \pm 0.01$ & $76.6 \pm 4.3$ & na. & $6.5 \pm 0.9$ & $42.6 \pm 3.3$ & $1.1 \pm 0.2$ \\
Gambeya lacourtiana & $97.7 \pm 1.6$ & $0.003 \pm 8.4$ & $19.4 \pm 0.9$ & $22.8 \pm 0.5$ & $77.3 \pm 3.1$ & $2.4 \pm 0.1$ \\
Afrostyrax lepidophyllus & $2.05 \pm 0.1$ & $5.7 \pm 0.1$ & $0.5 \pm 0.002$ & $3.8 \pm 0.1$ & $47.6 \pm 0.7$ & $1.8 \pm 0.1$
\end{tabular}

\footnotetext{
${ }^{1}$ : Edible portion wet basis

2: Each value is the mean and standard deviation (SD) of 3 sample lots per species analyzed individually.

3: $\mu \mathrm{g} / 100 \mathrm{~g}$
} 


\subsection{Discussion}

\subsection{Proximate composition}

The fat, digestible carbohydrates and total energy contents in Panda oleosa and Poga oleosa were substantially high. Previous findings in P. oleosa from the Umudike rain forest and Oban National Park in Nigeria [26], revealed fat content of $68.2 \%$ and carbohydrate content of $25.38 \%$, falling in the range of the two fruits, in the present study. Then again, when compared to popular and widely consumed oil producing oil seeds such as soy beans (Glycine max) in Gabon and the Congo Basin forest region, it was found that the lipid content of both P. oleosa and P. oleosa seeds to be about 3 folds higher than the fat content reported in G. $\max (23.5 \%)$ [27]. Based on their high nutrient content, the species of $P$. oleosa and $P$. oleosa can be considered good sources of fat and dietary energy and could play a role in production of high energy foods such as complementary foods for weaning children and foods to address severe acute malnutrition in emergency situations among forest communities of sub Saharan Africa. On the other hand, the highest protein and fiber contents in A. lepidophyllus registered in the present study were higher than the contents of protein (7.7\%) and fiber (4.4\%) reported in A. lepidophyllus grown in Southern Nigerian [28]. The difference between the contents of protein and fiber in the fruits of A. lepidophyllus of the present study in Cameroon and that of Ene-Obong et al., [28], may possibly be due to differences in growth conditions, genetic variation, or probably due to differences in post- harvest handling, processing, storage conditions and stage of maturity [29]. The forest fruits of P. longifolia and G. lacourtiana were found to contain substantial amounts of carbohydrates. The carbohydrate content in these two forest fruits were higher than some commonly consumed fruits, such as bush mangoes (Irvingia gabonensis) (13.5\%) and bush butter fruits (Dacryodes edulis) (8.7\%) as reported by Jamnadass et al., [30] and Ricinodendron 
heudelotii (34.1\%) commonly referred to as "njangsang" in Cameroon and Nigeria as reported by [28]. However the protein and fat content of the fruits of P. longifolia and G. lacourtiana are considerably lower than the contents reported in I. gabonensis, D. edulis and R. heudelotii.

\subsection{Minerals}

Overall, the mineral contents in the forest fruits of P. Oleosa in the present study were in the range of the mineral contents reported in P. Oleosa [26] and commonly consumed forest fruits; $I$. gabonensis and D. eduli [30]. The essential minerals of iron, zinc, calcium, magnesium and sodium in the fruits of $P$. Oleosa of the present study, were in the range of the previous findings of the same species. A range of $22.1-22.2 \mathrm{mg} / 100 \mathrm{~g}$ for iron, a range of $6.7-6.7 \mathrm{mg} / 100 \mathrm{~g}$ for zinc, a range of $8.9-9.2 \mathrm{mg} / 100 \mathrm{~g}$ for calcium and a range of $10.0-10.12 \mathrm{mg} / 100 \mathrm{~g}$ for magnesium has been reported in P. Oleosa growing in Umudike rain forest and Oban National Park of Nigeria [26]. Whereas the mineral contents in the fruits of P. longifolia and G. lacourtiana fall in the range of commonly consumed forest fruits such as the African pearwood (Bailonella toxisperma), a number of specific minerals were observed to be substantially lower than the contents reported in the commonly consumed fruits of the African oil bean (Pentaclethra macrophylla) and Trichoscypha abut [8]. For example the calcium, iron, zinc and selenium contents registered in the fruits of $P$. longifolia are comparable with calcium $(37.5 \mathrm{mg} / 100 \mathrm{~g})$, iron $(3.3 \mathrm{mg} / 100 \mathrm{~g})$, zinc $(0.2 \mathrm{mg} / 100 \mathrm{~g})$ and selenium $(0.1 \mu \mathrm{g} / 100 \mathrm{~g})$ contents reported in $B$. toxisperma [8]. However the potassium and phosphorous, contents in the five forest fruits in the present study, are lower than contents reported in B. toxisperma and P. macrophylla [8].

On the other hand, the iron, zinc and selenium contents registered in the fruits of A. lepidophyllus of the present study were comparable to contents registered previously in the same species 
harvested in Southern Nigeria [28]. Ene-Obong et al., [30] iron content of $24.3 \mathrm{mg} / 100 \mathrm{~g}$, zinc content of $5.7 \mathrm{mg} / 100 \mathrm{~g}$ and selenium content of $0.01 \mu \mathrm{g} / 100 \mathrm{~g}$ in Nigerian A. lepidophyllus fruits. Notwithstanding, the contents of calcium, potassium, sodium, phosphorous and magnesium previously reported in the Nigerian fruits of A. lepidophyllus by Ene-Obong et al., [28] are remarkably higher than the contents of the same species reported in the present study. The difference between the contents from the two studies may be attributable to genetic variation, or probably due to differences in post- harvest handling and stage of maturity [29].

\subsection{Bioactive compounds}

Vitamin $C$, $\beta$-carotene, Vitamin E, flavonoids, polyphenols and proanthocyanins

Overall the fruits of G. lacourtiana contained considerably high contents of flavonoids, proanthocyanins, polyphenols, Vitamins $\mathrm{C}$ and $\mathrm{E}$, than the values reported for some forest foods and commonly consumed plant foods in Gabon. Vitamin C content of the fruits of G. lacourtiana is more than 13 folds higher than the content reported in forest fruits of $R$. heudolitii (7.5 $\mathrm{mg} / 100 \mathrm{~g}$ ), more than 11 folds higher than the content reported in Tamarindus indica $(9.0$ $\mathrm{mg} / 100 \mathrm{~g})$, more than three folds the content in D. eduli $(32.1 \mathrm{mg} / 100 \mathrm{~g})$ and about two folds higher than the content in I. gabonensis $(66.4 \mathrm{mg} / 100 \mathrm{~g})$ and Sclerocarya birrea Hochst $(68.0$ $\mathrm{mg} / 100 \mathrm{~g}$ ) [30-32]. G. lacourtiana vitamin C content recorded in this study is about ten folds higher than the content reported in desert bananas (Musa acuminate) $(9.7 \mathrm{mg} / 100 \mathrm{~g})$ and about two folds higher than that of papaya $(51.2 \mathrm{mg} / 100 \mathrm{~g})$ [33]. The highest flavonoid content in the fruits of G. lacourtiana was comparable or considerably higher than the flavonoid content in some popular wild forest foods in West and Central Africa [34,35]. Flavonoid content in the fruits of G. lacourtiana of the present study is falls in the range of previously reported contents of several forest fruits including; Vitellaria paradoxa $(20.7 \mathrm{mg} / 100 \mathrm{~g})$, Adansonia digitata (31.7 
mg/100g), Dialium guineense (19.45 mg/100g) and Diospyros mespiliformis (22.4 mg/100 g). It is also about 14, 13, 10 and 2 times the values reported in forest fruits of Saba Senegalensis (1.7 $\mathrm{mg} / 100 \mathrm{~g}), \quad$ T. indica $(2.2 \mathrm{mg} / 100 \mathrm{~g})$ and Gardenia erubescens $(11.7 \mathrm{mg} / 100 \mathrm{~g})$ respectively. Despite the fruits of $G$. lacourtiana having the highest phenolic contents, generally the five sampled fruits have low phenolic contents, as compared to the widely consumed forest fruits in Gabon and the rest of the Congo basin forest region $[8,34,36]$. For instance, previous studies have registered remarkably high phenolic contents of $300.0 \mathrm{mg} / 100 \mathrm{~g}$ in bush butter fruits of $D$. edulis, $364.0 \mathrm{mg} / 100 \mathrm{~g}$ in Ricinodendron heudelotii, $671.8 \mathrm{mg} / 100 \mathrm{~g}$ in the African oil fruits of $P$. macrophylla, $686.7 \mathrm{mg} / 100 \mathrm{~g}$ in the African pear fruits of B. toxisperma, $947.0 \mathrm{mg} / 100 \mathrm{~g}$ in T.abut, $957.3 \mathrm{mg} / 100 \mathrm{~g}$ in T. indica, $1,347 \mathrm{mg} / 100 \mathrm{~g}$ in Aframomum citratum and 3,518.3 $\mathrm{mg} / 100 \mathrm{~g}$ in $A$. digitata [8,34-36]. Nonetheless, the phenolic content of the fruits of $A$. lepidophyllus growing in Gabon in the present study, is 5 times less the content $(212.0 \mathrm{mg} / 100 \mathrm{~g})$ reported in A. lepidophyllus growing in natural habitants of Yaoundé natural forests of Cameroon [36], while on the other hand, it is 4 times higher than the content $(12.0 \mathrm{mg} / 100 \mathrm{~g})$ reported in similar species grown in Southern Nigeria [28]. The variation in the contents from the three studies can be attributed to differences in post- harvest handling of samples, stage of maturity or genetic variation [29]. Additionally, the phenolic contents in the forest fruits, in the present study, are comparable to the contents previously reported in common tropical fruits including; mangoes (Mangifera Indica) (72.2 mg/100g), apples (Malus pumila) (45.8 mg/100g) papaya spp (75.4 mg/100g), pineapples (Ananas comosus) $\left(66.3 \mathrm{mg} / 100 \mathrm{~g}^{1}\right)$ and Cavendish bananas $(44.5 \mathrm{mg} / 100 \mathrm{~g})[33,37,38]$. The phenolic contents of forest fruits in this study reveal that these fruits can be alternative source of bioactive phenolic phytochemicals that can provide essential nutraceutical benefits compared to common tropical fruits. 
The fruits of $P$. oleosa contained the highest proathocyanins and vitamin E contents. The vitamin E content registered in the fruits of $P$. oleos $a$ were considerably higher than the contents reported in some of the forest fruits including; T. abut $(0.02 \mu \mathrm{g} / 100 \mathrm{~g})$ and B. toxisperma $(9.3 \mu \mathrm{g} / 100 \mathrm{~g})$ from Cameroonian forests [8] and Parkia biglobosa (18.1 $\mu \mathrm{g} / 100 \mathrm{~g})$ from Nigeria [39]. Furthermore, the vitamin E content in P. oleosa, P. oleosa and G. lacourtiana, are 20 times higher than, the content previously reported in imported fruits including; mangoes ( $M$. indica) $(1.1 \mu \mathrm{g} / 100 \mathrm{~g})[40]$ and in the citrus fruits of lemon (Citrus limon (L.) Osbeck), oranges (Citrus reticulate), tangerine (Citrus Reticulate) and Vitis vinifera (grapes), which have negligible contents [41].

However, the results of this study revealed that the five forest fruits were not good sources of proanthocyanins and $\beta$-carotene. For example the highest registered proanthocyanins content (7.6 $\mu \mathrm{g} / 100 \mathrm{~g}$ ) registered in the fruits of $P$. Oleosa is about 9 folds less, the content previously reported in Cameroonian forest fruits of P. macrophylla $(65.0 \mu \mathrm{g} / 100 \mathrm{~g})$ and $T$. abut $(61.2$ $\mu \mathrm{g} / 100 \mathrm{~g})$ and 4 folds the content in B. toxisperma $(28.0 \mu \mathrm{g} / 100 \mathrm{~g})$. Also, the highest $\beta$-carotenoid content in the present study registered in the fruits of $P$. longifolia, is remarkably lower than the values reported in commonly consumed $\beta$-carotene rich foods such as papaya $(232.3 \mu \mathrm{g} / 100 \mathrm{~g})$, desert bananas $(96.9 \mu \mathrm{g} / 100 \mathrm{~g})$ and East African highland cooking bananas (Musa spp.) (337.0 $\mu \mathrm{g} / 100 \mathrm{~g}$ ) $[33,42]$. The low levels of proanthocyanins and $\beta$-carotene in the present study may be attributed to the prolonged hours of transporting samples from the remote sites in Gabon to the nutrition laboratory at Yaoundé I University in Cameroon, for analyses. As a result of the unsaturated chemical structures of proanthocyanins and $\beta$-carotene, it is exposure to UV light 
and oxygen, may lead to isomerization and oxidation, thus reducing their contents in food samples [19].

Despite the variation in the concentration of proanthocyanins, flavonoids, polyphenols, $\beta$ carotene, vitamins $\mathrm{C}$ and $\mathrm{E}$ in the fruits reported in this study, these compounds have potentials to promote antioxidant activity, a precursor to prevent diseases mediated by oxidative stress [43]. Furthermore, pharmacological studies reveal that flavonoids, phenols and proanthocyanins, in low contents, have potentials to substantially reduce diarrhea and diabetes among humans [44]. The leaves and seeds of $G$. lacourtiana are used in the treatment of anemia and stomachache, among rural communities of Gabon while the A. lepidophyllus is used in the treatment of postpartum infections among women [45]. Also, the oil producing seeds of B. toxisperma are used by the Baka pygmies in both Cameroon and Gabon, to treat rheumatism and child birth shocks $[8,46]$.

\subsection{Impact of the nutritional value of forest fruits on dietary essential nutrient intake}

The amount of local foods (such as forest fruits) eaten traditionally by forest populations in Gabon, is estimated at around $200 \mathrm{~g}$ and $300 \mathrm{~g}$ daily respectively for children aged 1-3 years and non-lactating and non-pregnant women aged between 19 and 60 years [8,25]. Forest fruits in the Congo basin countries including Gabon and Cameroon are often eaten daily as snacks by children or by adults in between main meals or during performing household income activities such as farming or hunting $[9,47]$. Accordingly, using these estimations for the amounts that may be consumed, it is probable to determine the contribution of the forest fruits on meeting the RDIs of the essential nutrients $[48,49]$. 
The calculated potential contribution of the five forest fruits in the present study in reference to intakes of the energy and key essential nutrients such as magnesium, iron, zinc, vitamins $\mathrm{C}$ and E, revealed that with exception of fruits of $G$. lacourtiana not being a good source of magnesium, these foods can provide considerable amounts of these nutrients to both women and children (Table 4). For example, if a non-lactating and non-pregnant woman and a child aged 1 to 3 years ate $300 \mathrm{~g}$ and $200 \mathrm{~g}$ respectively daily, they would both obtain their $100 \% \mathrm{RDI}$, for magnesium (1000 mg/day for women and 500mg for children), iron (58.8 mg/day for women and $11.6 \mathrm{mg} /$ day for children) and zinc (12 mg/day for women and $4.5 \mathrm{mg} /$ day for children), from consumption of either P. oleosa, P. oleosa, G. lacourtiana and A. lepidophyllus. Also, $100 \% \mathrm{RDI}$ for vitamin E requirement of $0.4 \mathrm{mg} /$ day for children and $19 \mathrm{mg} / \mathrm{day}$ for women would be met by the fruits of P. oleosa, P. oleosa and G. lacourtiana. About $30 \%$ to $100 \%$ of RDI for energy requirements $(1,236.5 \mathrm{Kcal}$ for children and 3,000Kcal for women) and vitamin $\mathrm{C}$ requirements (45 mg/day for women and $30 \mathrm{mg} /$ day for children) would also be met by $P$. oleosa, P. oleosa, P. longifolia and G. lacourtiana. However, studies on bioavailability of these foods have not yet been carried out. Thus, further studies are needed to confirm the contribution of these foods to meeting the nutrient requirements. 
Table 4: Estimated nutreint contribution of average portion $\operatorname{size}^{1}$ of fruits to the recommended dietary allowamnce (RDA) for children aged 1-3 years and women aged 19-60 years

\begin{tabular}{|c|c|c|c|c|c|c|}
\hline Nutrients & Unit & $\begin{array}{l}\text { Panda } \\
\text { oleosa }\end{array}$ & $\begin{array}{l}\text { Poga } \\
\text { oleosa }\end{array}$ & $\begin{array}{l}\text { Pseudospondias } \\
\text { longifolia }\end{array}$ & $\begin{array}{l}\text { Gambeya } \\
\text { lacourtiana }\end{array}$ & $\begin{array}{l}\text { Afrostyrax } \\
\text { lepidophyllus }\end{array}$ \\
\hline \multirow[t]{2}{*}{ Energy $(\mathrm{Kcal})^{2}$} & $\%$ RDA $1-3 y$ & 99.6 & 114.7 & 60.8 & 61.1 & 36.0 \\
\hline & $\%$ RDA $19-60 y$ & 61.6 & 70.9 & 37.6 & 37.8 & 22.3 \\
\hline \multirow[t]{2}{*}{$\mathrm{Na}$} & $\%$ RDA 1-3y & 12.7 & 10.2 & 9.4 & 18.9 & 4.4 \\
\hline & $\%$ RDA $19-60 y$ & 15.2 & 12.2 & 11.2 & 22.7 & 5.2 \\
\hline \multirow[t]{2}{*}{ K } & $\%$ RDA $1-3 y$ & 0.0005 & 0.0003 & 0.0008 & 0.0009 & 0.0003 \\
\hline & $\%$ RDA $19-60 y$ & 0.0006 & 0.0003 & 0.0009 & 0.0011 & 0.0003 \\
\hline \multirow[t]{2}{*}{$\mathrm{Ca}$} & $\%$ RDA $1-3 y$ & 0.0 & 3.24 & 16.6 & 0.00 & 28.6 \\
\hline & $\%$ RDA $19-60 y$ & 0.0 & 2.4 & 12.5 & 0.00 & 21.5 \\
\hline \multirow[t]{2}{*}{$\mathrm{Mg}$} & $\%$ RDA 1-3y & 35.0 & 36.3 & 71.0 & 0.01 & 295.0 \\
\hline & $\%$ RDA $19-60 y$ & 14.3 & 14.9 & 29.1 & 0.00 & 120.7 \\
\hline \multirow[t]{2}{*}{$\mathrm{Fe}$} & $\%$ RDA 1-3y & 294.8 & 355.2 & 75.9 & 41.4 & 405.2 \\
\hline & $\%$ RDA $19-60 y$ & 87.2 & 105.1 & 22.5 & 12.2 & 119.9 \\
\hline \multirow[t]{2}{*}{$\mathrm{Zn}$} & $\%$ RDA $1-3 y$ & 453.3 & 333.3 & 8.9 & 293.3 & 40.0 \\
\hline & $\%$ RDA $19-60 y$ & 255.0 & 187.5 & 5.0 & 165.0 & 22.5 \\
\hline \multirow[t]{2}{*}{$\mathrm{Se}$} & $\%$ RDA $1-3 y$ & 10.3 & 1.5 & 0.4 & 2.9 & 0.3 \\
\hline & $\%$ RDA $19-60 y$ & 11.0 & 1.6 & 0.4 & 3.0 & 0.3 \\
\hline \multirow[t]{2}{*}{ Vitamin C } & $\%$ RDA $1-3 y$ & 44.7 & 30.7 & 212.0 & 651.3 & 14.1 \\
\hline & $\%$ RDA 19-60y & 44.6 & 31.0 & 242.0 & 651.3 & 13.7 \\
\hline \multirow[t]{2}{*}{ Vitamin $A R^{3}$} & $\%$ RDA $1-3 y$ & 1.4 & 1.43 & 6.4 & 0.00025 & 0.5 \\
\hline & $\%$ RDA $19-60 y$ & 1.7 & 1.71 & 7.7 & 0.0003 & 0.6 \\
\hline \multirow[t]{2}{*}{ Vitamin E } & $\%$ RDA $1-3 y$ & 1160.0 & 1070.0 & 0 & 970.0 & 25.0 \\
\hline & $\%$ RDA $19-60 y$ & 1740.0 & 1605.0 & 0 & 1455.0 & 37.5 \\
\hline
\end{tabular}

${ }^{1}$ : In the Congo Basin forest region, a child aged 1-3 years, his or her daily food intake is estimated to be $200 \mathrm{~g}$, while a non- lactating non- pregnant woman aged between 19 and 60 years, on average consumes $300 \mathrm{~g}$ daily $[8,25]$.

2: Energy requirement for African population calculated as a function of estimated weight (60kgs) and height (1.55meters) among Africans [50]: Retinol equivalents (REs) (conversion factor 6:1 from $\beta$-carotene equivalents to RE) [48].

3: The nutrient contribution of an average portion of fresh fruit to nutrient intake recommendations of individuals was calculated and expressed as a percentage of the Dietary Reference Intakes (DRI) (recommended dietary allowance [RDA], for 1-3-year-old children and non-pregnant non-breastfeeding females [8,25]. 


\subsection{Conclusions}

The five forest fruits were nutritionally diverse, with $P$. oleosa, P. oleosa, G. lacourtiana and A. lepidophyllus exhibiting high content of bioactive compounds including vitamins $\mathrm{E}$ and $\mathrm{C}$. While G. lacourtiana and P. oleosa fruits had the highest bioactive contents of flavonoids, polyphenols, proanthocyanins and vitamins $\mathrm{C}$ and $\mathrm{E}$, the fruits of $A$. lepidophyllus and P. oleosa had the highest essential minerals content of iron, zinc, selenium, calcium and magnesium. Based on the nutritional values of these forest fruits, it can be concluded that the five forest fruits can make considerable contributions towards meeting nutrient requirements, for iron, zinc, magnesium, vitamins $\mathrm{C}$ and $\mathrm{E}$. These forest fruits are also good sources of health promoting bioactive compounds. There is need to disseminate information about the nutritional and bioactive compositions of these fruits to promote their consumption. It is also recommended that the greater number of forest foods in Gabon and other African countries with unknown nutrient contents should be analyzed and the results distributed and used for formulating policies governing food and nutrition security.

\section{Acknowledgments}

The authors are grateful to all participants in the surveys, including colleagues from IRET and the key informants in forest concessionaires of CEB and CPAET-Bayonne. Our most sincere gratitude goes to the forest concessionaires that allowed entering into their forest concessions, the villagers that patiently sacrificed the time in responding to lengthy questionnaires and the Ministry of forestry for their outstanding collaboration.

\section{Funding}

This study was done in the framework of "Beyond Timber project", under a grant 5650155000601 from the Congo Basin Forest Fund of the African Development Bank to 
Bioversity International and by the CGIAR Research Programme on Forests, Trees and Agroforestry.

Author Contributions: All authors jointly conceived, designed and implemented the study. FR performed the analyses and wrote the first draft of this article, to which the rest of the other authors provided input.

Conflict of interest: None declared.

\section{References}

1. Iponga, D.M.; Mikolo-Yobo, C.; Lescuyer, G.; Mba-Assoumou, F.; Levang, P.; Tieguhong, J.C.; Ngoye, A. The contribution of NTFP-gathering to rural people's livelihoods around two timber concessions in Gabon. Agroforest Syst, 2017, 92, 157-168.

2. Ezzati, M.; Vander, H.S.; Rodgers, A.; Lopez, A.D.; Mathers, C.D.; Murray, C.J. Estimates of global and regional potential health gains from reducing multiple major risk factors. Lancet, 2003, 362, 271-80.

3. Donn, P.; Ngondi, J.L.; Tieguhong, J.C.; Iponga, D.M.; Tchingsabe, O.; Fungo, R.;

Tchatat, M.; Kahindo, J.M. Poverty and poor education are key determinants of high household food insecurity among populations adjoining forest concessions in the Congo Basin. BMC Nutrition, 2016, 2, 35.

4. Gabon Demographic and Health Survey [DGS/Gabon] and ICF International. (2013); Enquête Démographique et de Santé du Gabon 2012. Calverton, Maryland, and Libreville, Gabon: DGS/Gabon and ICF International. Available online: https://dhsprogram.com/pubs/pdf/FR276/FR276.pdf (accessed on 1st April 2018). 
5. Lock, K.; Pomerleau, J.; Causer, L.; Altmann, D.R.; McKee, M. The global burden of disease attributable to low consumption of fruit and vegetables: Implications for the global strategy on diet. Bull World Health Organ 2005,83, (2),100-108.

6. Kant, A.K. Dietary patterns and health outcomes. J Am Diet Assoc, 2004, 104, 615-635.

7. Siawaya, D.J.F.; Mombo, R.B.; Obame, A.A.S.; Alame, E.A.K.; Rerambiah, L.K. Prevalence and Relationship between Hyperglycemia Hypertension and Obesity in Libreville-Gabon: A Pilot Study. Endocrinol Diabetes Res, 2015, 1:1.doi:10.4172/24707570.1000102

8. Fungo, R.; Muyonga, J.; Kaaya, A.; Okia, C.; Tieguhong, J.C.; Baidu-Forson, J.J. Nutrient quality and bioactive compounds of Baillonella toxisperma, Trichoschypa abut and Pentaclethra macrophylla from Cameroon. Food Sci Nutr, 20153 (4): 292-301.

9. Fungo, R.; Muyonga, J.; Kabahenda, M.; Kaaya,A.; Okia, C.; Donn, P.; Tchtat, M.; Tchingsabe, O.; Tieguhong, J.C.; Loo, J.; Snook, L.. Contribution of forest foods to dietary intake and their association with household food insecurity: a cross-sectional study in women from rural Cameroon. Public Health Nutr, 2016a, 19 (17), 3185-3196.

10. Onimawo, I.A.; Oteno, F.; Orokpo, G.; Akubor, P. I. . Physicochemical and nutrient evaluation of African bush mango (Irvingia gabonensis) seeds and pulp. Plant Foods Hum Nutr, 2003, 58,1-6.

11. Penafiel, D.; Lachat, C.; Espinel, R.; VanDamme, P.; Kolsteren, P. Systematic review on the contributions of edible plant and animal biodiversity to human diets. EcoHealth, $2011,8,381-399$. 
12. Fungo, R.; Muyonga, J.H.; Kabahenda, M.; Okia, C.A.; Snook, L. Factors influencing consumption of nutrient rich forest fruitss in rural Cameroon. Appetite, 2016b, 97 (1), $176-184$.

13. Massoukou, L. La re'trocession d'une partie des revenus de l'exploitation forestie 're aux populations locale Gabonaises: efficacite', e'quite's et pe'rennite', 2007. Me'moire de Stage, ENGREF, Montpellier.

14. Mba-Assoumou, F. Caracte'risation des usages locaux des produits forestiers dans les concessions forestie'res en Afrique Centrale: cas de deux concessions forestie 'res: la CFAD CEB-PreciousWoods et la CPAET Bayonne au Gabon, 2012. Me'moire de fin de cycle pour l'obtention du diplo^me de Master 2, En Sciences et technologies, mention Agronomie et Agroalimentaire, Spe'cialite': Gestion Environnementale des Ecosyste`mes et Fore^ts Tropicales.

15. AOAC. (2006). Official methods of analysis , 18th edn, 2006. Association of Official Analytical Chemist, Washington, DC.

16. Greenfield, H.; Southgate, D.A.T. Food Composition Data: Production, Management and Use, 2nd edN, 2003. Food and Agriculture Organization of the United Nations, Rome.

17. Amin, I.; Zamaliah, M.M. ; Chin, W.F. Total antioxidant activity and phenolic content in selected vegetables. Food Chem, 2004, 87,581-586.

18. Zhishen, J.; Mengcjheng, T.; Jianming, W.. The determination of flavonoid contents in mulberry and their scavenging effects on superoxide radicals. Food Chem 1999, 64, 555559.

19. Georgé, S.; Brat, P.; Alter, P.; Amiot, M.J. Rapid determination of polyphenols and vitamin C in plantderived products. J Agric Food Chem 2005, 53, 1370-1373. 
20. Giusti, M.M.; Rodriguez-Saona, L.E.; Wrolstad, R.E. Molar absorptivity and color characteristics of acylated and non- acylated pelargonidin- based anthocyanins. J Agric Food Chem 1999, 47,4631- 4637.

21. AOAC. Official methods of analysis, 18th edn 2005. Association of Official Analytical Chemists, Gaithersburg, MD.

22. Vanderslice, J.T.; Higgs, D.J. Separation of ascorbic acid, isoascorbic acid, and dehydroascorbic acid in food and animal tissue. Jour of Micronutrient Analysis 1990. 7, $67-70$.

23. Otten, J.J.; Hellwig, J.P.;Meyers, L.D. (Eds.) . Dietary Reference Intakes: The Essential Guide to Nutrient Requirements, 2006. The National Academies Press, Washington, DC, USA.

24. Ross, A.C.; Manson, J.E.; Abrams, S.A.; Aloia. J.F. ; Brannon, P.M. ; Clinton. S.K.; Durazo-Arvizu, R.A.; Gallagher, J.C.; Gallo, R.L.; Jones, G.; Kovacs, C.S.; Mayne, S.T.; Rosen, C.J.; Shapses, S.A. (2011). The 2011 dietary reference intakes for calcium and vitamin D: what dietetics practitioners need to know. Journal of the American Dietetic Association, 2011, 111, 524-527.

25. Yamauchi, T.; Sato, H.; Kawamura, K. Nutritional status, activity pattern, and Dietary intake among the Baka hunter-gatherers in the village camps in Cameroon. African Studies Monograph 2000, 21, 67-82.

26. Dike, M.C.; Asuquo, M.E. Proximate, phytochemical and mineral compositions of seeds of Allanblackia floribunda, Garcinia kola and Poga oleosa from Nigerian rainforest. African Journal of Biotechnology, 2012, 11(50) 11096-11098. 
27. Olaofe, O.; Akintayo, E.T.; Adeyeye, E.I.; Adubiaro, H.O. Proximate Composition and functional properties or Bulma cotton (Bombcapsis glabra) seed. Egypt J Food Sci, 2006, $34,81-90$.

28. Ene-Obong, H.; Onuoha, N.; Aburime, L.; Mbah, O. Chemical composition and antioxidant activities of some indigenous spices consumed in Nigeria. Food Chem, 2017, $238,58-64$.

29. Rodriguez-Amaya, D.B.; M. Kimura. HarvestPlus handbook for Carotenoid analysis . HarvestPlus Tech. Monogr, 2004, Ser. 2:1-78.

30. Jamnadass, R.; Place, F.; Torquebiau, E.; Malézieux, E; Iiyama, M.; Sileshi, G.W.; Kehlenbeck, K.; Masters, E., McMullin, S.; Weber, J.C.; Dawson, I.K. Agroforestry, food and nutritional security. ICRAF Working Paper, 2013, No. 170. Nairobi, World Agroforestry Centre. DOI: http://dx.doi.org/10.5716/WP13054.PDF

31. Ejiofor, M.A.N.; Onwubuke, S.N.; Okafor, J.C. Developing improved methods of processing and utilization of kernels of Irvingia gabonensis (var.gabonensis and var.excelsa). Int. Tree Crops J, 1987,4 :283- 290.

32. Kehlenbeck, K.; Asaah, E.; Jamnadass, R. Diversity of indigenous fruit trees and their contribution to nutrition and livelihoods in sub-Saharan Africa: examples from Kenya and Cameroon. 2013, Pp. 257-269. in J. Fanzo, D. Hunter, et al., eds. Diversifying food and diets: using agricultural biodiversity to improve nutrition and health issues in agricultural biodiversity. Earthscan, London.

33. Marisa, M.W. Ascorbic acid, vitamin A, and mineral composition of banana (Musa sp.) and papaya (Carica papaya) cultivars grown in Hawaii. J Food Compos Anal $2006,19,434-445$. 
34. Leakey, R.R.B. Potential for novel food products from agroforestry trees. Food. Chem, 1999, 64:1-14.

35. Lamien-Meda, A.; Lamien, C.E. ; Compaoré, M.M.Y.; Meda, R.N.T. ; Kiendrebeogo, M. ; Zeba, B. ; et al. Polyphenol content and antioxidant activity of fourteen wild edible fruits from Burkina Faso. Molecules, 2008, 13:581- 594.

36. Agbor, G.; Talla, L.; Ngogang, J.Y. The antidiarrhoeal activity of Alchornea cordifolia leaf extract. Phytother Res, 2004, 18, 873-876.

37. Mélo, E.A.; Lima, V.L. A.G.; Maciel, M.I.S. Polyphenol, Ascorbic Acid and Total Carotenoid Contents in Common Fruits and Vegetables. Braz. J. Food Technol. 2006, $9(2), 89-94$.

38. Chang, Y.L. Common Nutrients and Nutraceutical Quality of Apples. New York Fruit Quarterly, 2012, 20,3.

39. Olujobi, O.J. Comparative evaluation of nutritional composition of African locust bean (Parkia biglobosa) fruits from two locations. Nigerian J. Basic Appl. Sci. 2012, 20: 195 $-198$.

40. Lauricella, M.; Emanuele, S.; Calvaruso, G.; Giuliano, M.; D’Anneo, A. Multifaceted health benefits of mangifera indica L. (Mango): The inestimable value of orchards recently planted in sicilian rural areas. Nutrients 2017, 9(5), 525.

41. YuQiu, L.; Heying, E.; Tanumihardjo, S.A.. Global Distribution and Nutritional lmportance of Citrus Fruits. Compr Rev Food Sci F, 2012, 11,530-545.

42. Fungo, R.; Kikafunda, J. K.; Pillay, M. Betacarotene, iron and zinc content in Papua New Guinea and East African Highland Bananas. Afr j food agric nutr dev, 2010, 10, 26292644. 
43. Floegel, A.; Kim, D.; Chung, S.J.; Koo, S.I.; Chun, O.K. Comparison of ABTS/DPPH assays to measure antioxidant capacity in popular antioxidant-rich US foods. J. Food Compos. Anal, 2011, 24,1043-1048.

44. Agbor, G.A.; Oben, J.E.; Ngogang, J.Y.; Cai, Xinxing.; Vinson, J.A. Antioxidant capacity of some herbs/spices from Cameroon: a comparative study of two methods. $J$ Agric Food Chem, 2005, 53:6819-24.

45. Towns, A.M.; Mengue, Eyi, S.; van Andel, T. Traditional Medicine and Childcare in Western Africa: Mothers' Knowledge, Folk Illnesses, and Patterns of HealthcareSeeking Behavior. PLoS ONE, 2014, 9 (8): e105972.

46. Jiofack, T.; Fokunang, C.; Guedje, N.; Kemeuze, V.; Fongnzossie, E.; Nkongmeneck, B. A. Mapongmetsem PM and Tsabang N, Ethnobotanical uses of medicinal plants of two ethnoecological regions of Cameroon. Int J Med Sci, 2010, , 2,60-79.

47. Ickowitz, A.; Rowland, D.; Powell, B.; Salim, M.A.; Sunderland. T. Forests, Trees, and Micronutrient-Rich Food Consumption in Indonesia. PLoS ONE, 2016, 11(5): e0154139. https://doi.org/10.1371/journal.pone.0154139

48. FAO/WHO. Vitamin and mineral requirements in human nutrition. Food and Agriculture Organization of the United Nations Rome and World Health Organization, 2004, Geneva.

49. Ruel, M.T.; Minot, N.; Smith, L. Patterns and determinants of fruit and vegetable consumption in sub-Saharan Africa: a multi-country comparison. Report of the Joint WHO/FAO Workshop on Fruit and Vegetables for Health, 2004, Kobe Japan. Available from www.who.int/dietphysicalactivity/fruit/en/index1.html (Accessed February 10th 2018). 
50. Shetty, P.S.; Henry, C.J.K.; Black, A.E.; Prentice, A.M. Energy requirements of adults: an update on basal metabolic rates (BMRs) and physical activity levels (PALs). Eur J Clin Nutr 1996; 50 (Supp1. 1): S11-S23 